Original Scientific Article

\title{
REPLACEMENT OF FISH MEAL BY RIBOTRICIN IN DIETS OF CARP (CYPRINUS CARPIO)
}

\author{
Alexandar Pavlov Atanasoff \\ Trakia University, Faculty of Veterinary Medicine, Department of Animal husbandry, \\ Stara Zagora 6014, Bulgaria
}

Received 24 July 2013; Received in revised form 30 September 2013; Accepted 20 October 2013

\begin{abstract}
Waste non-standard fish combined with wheat bran filler in ratio 60:40 were used for production of new non-traditional protein component called Ribotricin. The aim of this study was to elucidate the effects of the new protein component Ribotricin on growth performance, feed utilization and feed ingredients digestibility of carp (Cyprinus carpio L., 1758) fish. The experiment (90 days) involved 160 carp reared in eight concrete tanks with an initial average weight of $0.046 \pm 8.04 \mathrm{~g}$ in (RT) tank, and fish with an initial average weight of $0.047 \pm 6.52 \mathrm{~g}$ in (FM) tanks. The experimental carp were equally divided into two groups of 80 (four replicates of 20 carp each). The obtained results at the end of the experiment, showed no significant differences between the groups` Body Weight (BW), Feed Conversion Ratio (FCR), Specific Growth Rate (SGR), Protein Efficiency Ratio $(\mathrm{PER})(\mathrm{p}>0.05)$. Based on the obtained data, we can conclude that Ribotricin (RT) can be used as fish meal substitution in the diets of carp fish without adverse effects on the measured parameters.
\end{abstract}

Key words: carp; fish meal; feed conversion ratio; specific growth rate

\section{INTRODUCTION}

The minimum content of nutrients in the blend for fish is determined by scientific standards (1). The needs in amino acids vary depending on the species, growing technology, and the water temperature (2). Lysine, methionine, tryptophan, and arginine are the limiting essential amino acids which determine the growth and development of carp. Balanced content of these amino acids and the content of protein normally ensure sufficient quantity and the rest of the ration (3). Fishmeal contains three major nutrients; protein, fat and minerals. The protein in fishmeal is an excellent source of the aforementioned amino acids lysine,

Corresponding author: Assist. Prof. Alexandar Atanasoff, $\mathrm{PhD}$ E-mail address:hmi atanasoff@mail.bg

Present address: Department of Animal husbandry,

Faculty of Veterinary Medicine - Stara Zagora, Trakia University,

Students campus 2, 6014 Stara Zagora, Bulgaria

tel: +35942 699 557; fax: +35942699500

Copyright: (C) 2014 Atanasoff A. This is an open-access article published under the terms of the Creative Commons Attribution License which permits unrestricted use, distribution, and reproduction in any medium, provided the original author and source are credited.

Competing Interests: The authors have declared that no competing

interests exist.

Available Online First: 15 November 2013

http://dx.doi.org/10.14432/j.macvetrev.2013.10.004 methionine and tryptophan in finfish feeds (4). In recent years, replacement of fish meal with cheaper ingredients of either vegetable or animal origin in fish feed is necessary, because of the rising cost of raw materials and uncertain availability of fish meal (5). Nowadays, the research has focused on utilizing less expensive and readily available resources to replace fish meal, without reducing the nutritional quality of feed $(6,7,8,9)$. There are several protein sources that have the potential of replacing fishmeal in aquaculture feeds without affecting the growth performance of fish (10). Products like soybean, canola meals, fish silage and microalga, in particular, are widely used in animal nutrition because of their high protein content (40-50\%) low cost and relative availability. The nutritive value of a raw material depends on its chemical composition, the content of essential amino acids, carbohydrates, minerals and their availability to fish during the metabolic process (11) and water temperature (12).

The experiment tried to evaluate the replacement of fish meal by low cost waste nonstandard fish with wheat bran filler according to the method described by Ilieva et al $(13,14)$ for carp in recirculation system. 


\section{MATERIALS AND METHODS}

\section{Experimental Site}

The evaluation of compound feed containing Ribotricin was conducted by performing one experiment. The study was carried out at the Faculty of Agriculture, Trakia University, Bulgaria.

\section{Experimental System and Fish}

The experimental fish, carp (Cyprinus carpio) were procured from the freshwater fish farm Tundja73, Nikolaevo, Bulgaria. Animals were acclimatized for 5 (five) days before the commencement of the experiment. This was done in order for the fish to empty their stomach content and to force them to adjust to the new diet. The feeding trial was conducted in concrete tanks. The tanks were properly washed, disinfected and rinsed with clean water prior to the beginning of the study. The fish were stocked at a density of 20 in each of the tanks containing $700 \mathrm{~L}$ of dechlorinated bore water. The adequate level of oxygen in each tank was maintained through aeration.

\section{Diet Formulation and Preparation}

The ingredient composition and chemical content in the experimental diets are shown in Table 1 . The calculated daily ration was supplied in 5 equal rations: $08: 00 ; 10: 00 ; 12: 00,14: 00$ and $16.00 \mathrm{~h}$. This ration level was determined near to satiety according to rearing conditions.

\section{Experimental Procedure}

For the purpose of this study, the formulated diet was divided into two designated feed treatments: FM (with fish meal) and RT (with Ribotricin). The 8 tanks of 4 replicates were used as follows for the experiment. Feed FM (control diet): standard artificial carp feed, Feed RT: standard artificial carp feed with fully replaced fish meal.

The experiment was carried out for 90 days, while all analyses for proximate composition were determined according to the methods of Todorov et al., (15).

Water samples were collected every day from locations at the entrance and the end of cages (Table 2). Water temperature $\left({ }^{\circ} \mathrm{C}\right)$ was measured for $24 \mathrm{~h}$ with a digital thermometer. Dissolved oxygen, $(\mathrm{mg} / \mathrm{l})$, nitrate $(\mathrm{ppt})$ and active acidity $(\mathrm{pH})$ were determined using WTW-oxi330, HANNA HI 98312 and REDOX Zac plus.

\section{Measurement of growth parameters}

The growth parameters were measured according to the methods described by Todorov and Ivancheva (16). Before measurement, the fish were anesthetized with clove oil $\left(40 \mathrm{mg} \mathrm{L}^{-1}\right)$. Growth performance was calculated as follows:

Protein efficiency ratio (PER) was based on the mean weight gain of a fish divided by its intake of a particular food protein during the test period.

Table 1. Inclusion levels of ingredients in experimental diets and its proximate composition

\begin{tabular}{lccc}
\hline Feed ingredients & Unit & RT & FM \\
\hline Soybean meal & $\%$ & 31.3 & 24 \\
Corn & $\%$ & 16 & 20 \\
Wheat & $\%$ & & 20 \\
Fish meal & $\%$ & & 19 \\
Sunflower meal & $\%$ & 8 & 12 \\
Ribotricin & $\%$ & 39 & 4 \\
DCP & $\%$ & 4.7 & 0.5 \\
Salt & $\%$ & 0.5 & 0.5 \\
VM premix & $\%$ & 0.5 & 88.63 \\
Proximate composition & & & 11.37 \\
Dry matter & $\%$ & 89.94 & 30.44 \\
Moisture & $\%$ & 10.06 & 3.27 \\
Crude protein & $\%$ & 30.12 & 4.61 \\
Crude fat & $\%$ & 4.89 & 2420 \\
Crude fiber & $\%$ & 5.30 & 2394 \\
Digestible energy & $\mathrm{kcal}_{\mathrm{kg}}^{-1}$ & & \\
\hline
\end{tabular}


Table 2. The range of water quality parameters during the experimental period

\begin{tabular}{ccc}
\hline Parameters & Unit & Mean \pm SD \\
\hline D.O. & $\mathrm{mg} / 1$ & $8.65 \pm 0.52$ \\
Temperature & ${ }^{0} \mathrm{C}$ & $23.24 \pm 1.21$ \\
$\mathbf{p H}$ & & $7.33 \pm 0.31$ \\
NO$^{-}$ & $\mathrm{Ppt}$ & $35.8 \pm 1.08$ \\
\hline
\end{tabular}

$\mathbf{P E R}=\mathrm{W} /$ amount of protein fed

Feed conversion ratio (FCR) was determined by dividing the total weight of the food given by the total increase in weight gained by the fish over a period of time while feed intake (FI) was calculated as the addition of daily mean feed intake of the fish during the period.

$$
\mathbf{F C R}=\mathrm{FC} /\left(\mathrm{W}_{2}-\mathrm{W}_{1}\right)
$$

\section{RESULTS}

Group of 5 fish, randomly selected from each tank, were weighed every 45 days. The results of the growth parameters, feed conversion and protein efficiency ratios are shown in Table 3. Experimental fish utilized the two feeds at varying levels, which brought no significant variations $(\mathrm{p}>0.05)$ to growth parameters. At the start of the trial the Initial Body Weight (IBW) for the fish from the control group were $0.047 \pm 6.52$ and $0.046 \pm 8.04$ respectively for the fish from the experimental variant (Table 3 ). We should point out that even though it was not significant, the Final Body Weight of carp fed with FM was higher, but the differences were not statistically proven. Similar tendency was observed for PER, FCR and SGR. All three parameters were lower for the experimental treatment (fish fed with the Ribotricin supplement diet), compared with the

Table 3. Effect of different experimental feed on FCR, SGR, PER

\begin{tabular}{lccc}
\hline \multicolumn{1}{c}{ Control catch } & Unit & Ribotricin (RT) & Fish meal (FM) \\
\hline Start general biomass & $\mathrm{Kg}$ & 3.68 & 3.76 \\
Initial body weight & $\mathrm{Kg}$ & $0.046 \pm 8.04$ & $0.047 \pm 6.52$ \\
Final general biomass & $\mathrm{Kg}$ & 8.96 & 9.44 \\
Final body weight & $\mathrm{Kg}$ & $0.112 \pm 2.14$ & $0.118 \pm 4.04$ \\
PER & & 1.31 & 1.40 \\
FCR & $\mathrm{g} / \mathrm{g}^{-1}$ & 2.36 & 2.20 \\
SGR & $\%$ day $^{-1}$ & 2.07 & 2.15 \\
Survival & $\%$ & 100 & 100 \\
\hline
\end{tabular}

Specific growth rate (SGR) (\%/day): This is the relationship of the difference in the weight of the fish within the experimental period. Where $t$ is the period of culture in days, $\ln W_{0}$ is the natural logarithm of the weight of the fish at the beginning of the experiment, and $\ln W_{\mathrm{t}}$ is the natural logarithm of the weight of the fish at day $t$. ( $W_{0}$ and $W_{\mathrm{t}}$ are in gram).

$$
\text { SGR }=\left(\ln \mathrm{W}_{2}-\ln \mathrm{W}_{1}\right) /\left(\mathrm{t}_{2}-\mathrm{t}_{1}\right)^{-1} \times 100
$$

\section{Statistical analysis}

All data were expressed as mean $\pm \mathrm{SD}$. Data were subjected to analysis of variance (STATISTICA 6) to compare differences among individual means. values of these parameters received for the fish fed with the control diet (fish meal (FM). The obtained data for these performance traits was not significant ( $\mathrm{p}>0.05)$.

After 90 days of rearing, all fish were harvested from the recirculation system. The survival rate for all the fish was found to be $100 \%$ throughout the experimental period.

\section{DISCUSSION}

The measured temperature and dissolved oxygen were optimal for carp, because the optimal temperature must be in a range between 22 and $24^{\circ} \mathrm{C}$ 
and the oxygen level should not fall below $8 \mathrm{mg} / 1$ (2). The used experimental diet did not significantly change the $\mathrm{pH}$ of the water in the tanks.

Fishmeal is generally added to animal diets to increase feed efficiency and growth through better feed palatability; it enhances nutrient uptake, digestion, and absorption (17). However, the inconsistency of supply, the growing demand and price, among other problems, are limiting the use of fishmeal and putting greater pressure on the feed industry to find an economical alternative source of protein (18). The possibility of replacing fishmeal with fishery by-products, such as waste nonstandard fish, shrimp head meal and fish silage have been tested in various aquaculture feeds (19). Although not significant, the results received from the trial showed that fish fed with control diet consisting of fish meal exhibited higher growth rate (Final body weight, Feed conversion ratio, Protein efficiency ratio and Specific growth rate) when compared to carp fed with experimental diet. Our results were in accordance with the data obtained by Toledo et al. $(20,21)$. They replaced fishmeal with shrimp head meal in Israel tilapia (Oreochromis aureus) feed without any adverse effects on feed and growth efficiency. Similar data was received in research conducted to investigate the replacement of fish meal with fish silage in Nile tilapia (Oreochromis niloticus) $(22,23,24,25)$ and Mozambique Tilapia (Oreochromis mossambicus) (26). Carp species are omnivorous species and because of that they have the ability to assimilate alternative protein like tilapia. The results of the experiment showed that feeding fish on compound feeds containing Ribotricin had no negative effect on growth parameters. Based on the obtained data, the authors assumed that the Ribotricin is an adequate feed for carp and could be successfully used for substitution of fish meal.

\section{REFERENCES}

1. Sauvant, D., Perez, J., Tran, G. (2005). Tables of composition and nutritional value of feed materials pigs, poultry, cattle, sheep, goats, rabbits, horses, fish. ISBN 978-90-76998-41-1, Wageningen Academic Publ.

2. Zaykov, A. (2008). Aquaculture - principles and technology. Sofia Cabri Publ., ISBN 954-693-033-4.

3. Staykov, Y., Zaykov, A. (2013). Aquaculture. ISBN 954-693-118-5, Sofia Cabri Publ., 78.
4. Pike, I.H., Barlow, S.M. (2003). Impact of fish farming on fish stocks. International Aqua feed Directory, 24-29.

5. Abbas, S., Ahmed, I., Hafeez-UR-Rehman, M., Mateen, A. (2008). Replacement of fish meal by canola meal in diets for major carps in fertilized ponds. Pakistan Vet. J., 28 (3): 111-114.

6. EI-Sayed, A.F.M. (1999). Alternative dietary protein sources for farmed tilapia, Oreochromis spp. Aquaculture, 179 (1-4): 149-168.

7. Cheng, Z.J., Hardy, R.W., Usry, J.L. (2000). Plant protein ingredients with lysine supplementation reduce dietary protein level in rainbow trout (Oncorhynchus mykiss) diets and reduce ammonia nitrogen and soluble phosphorus excretion. Aquaculture, 218, 553-565.

8. Fournier, V., Huelvan, C., Desbruyeres, E. (2004). Incorporation of a mixture of plant feedstuffs as substitute for fish meal in diets on juvenile turbot (Psetta maxima). Aquaculture, 236, 451-465.

9. Sirakov, Y., Velichkova, K., Nikolov, G. (2012). The effect of algae meal (Spirulina) on the growth performance and carcass parameters of rainbow trout (Oncorhynchus mykiss). J. BioSci. Biotech, 151-156.

10. Tacon, A.G.J. (2004). Use of fish meal and fish oil in aquaculture: a global perspective. Aquatic Resources, Culture \& Development, 1 (1): 3-14.

11. Lanari, D., D'Agaro, E. (2005). Alternative plant protein sources in sea bass diets. Italian Journal Animal Science, 4, 365-374.

12. Hardy, R.W. (2002). Rainbow trout (Oncorhynchus mykiss). Nutrient Requirements and Feeding of Finfish for Aquaculture. C.D. Webster and C.E. Lim (eds). CABI Publishing, ISBN 0-85199-519-5, Wallingford, UK. p. 184-202.

13. Ilieva, J., Simovska, M., Tswetkova, V., Rangelova, S., Angelova, L. (1985). Ribotricin - a new nontraditional feed protein component. I. Ribotricin composition. Anim. Science., 22, 10, 51-56.

14. Ilieva, J., Valchev, G., Kolchagova, K., Klisurov, H., Tswetkova, V., Angelova, L. (1985). Ribotricin A new nontraditional feed protein component. II. Biological evaluation of compound feeds containing Ribotricin for pigs. Anim. Science, 22, (10), 57-62.

15. Todorov, N., Ilchev, A., Chobanova, S., Girginov, D., Ganchev, G., Penkov, D., Shindarska, Z., Mihailova, G., Naidenova, J., Nedelkov, K., Atanasov, A. (2010). Manual of animal nutrition. Sofia Iztok-Zapad Publ., ISBN: 978-954-321-733-5.

16. Todorov, M., Ivancheva, E. (1992). Manual of practical training in fish farming. Sofia Zemizdat Publ: 86. ISBN 954-05-0188-1. 
17. Miles, R.D., Chapman, F.A. (2006). The benefits of fish meal in aquaculture diets. Series of the Department of Fisheries and Aquatic Sciences University of Florida. FA 122, 7-8.

18. Hardy, R. W. (2010). Utilization of plant proteins in fish diets: effects of global demand and supplies of fishmeal. Aquaculture Research, 41 (5): pp. 770-776. doi: $10.1111 /$ j.1365-2109.2009.02349.x

19. Ayoola, A.A. (2010). Replacement of fishmeal with alternative source of proteins in aquaculture diets - MSc. Thesis (Submitted to the North Carolina State University Graduate School, Raleigh, North Carolina, United States. December, 2010)

20. Toledo, J., Ortiz, E., Gonzalez, B. (1986). Substitucion de la harina de pescado por harina de cefalo torax de camaron en dietas para alevines de Oreochromis aureus. Boletin Tecnico No.3, Empresa Nacional de Acuicultura, Ministeriode la Industria Pesquera, Habana, Cuba, 8p.

21. Toledo, J., Cisneros, J.A., Ortiz, E. (1987). Utilizacion de la harina de morralla en lugar de harina de pescado en la dieta de juveniles de tilapia, Oreochromis aureus. Investigaciones Marinas, 3:55-59, Empresa Nacional de Acuicultura, Ministeriode la Industria Pesquera, Habana, Cuba.
22. Fagbenro, O.A., Jauncey, K. (1993). Chemical and nutritional quality of stored fermented silage. Bioresource. Technol., 46, 207-211.

23. Fagbenro, O.A., Jauncey, K. (1994a). Chemical and nutritional quality of fermented fish silage containing potato extracts, formalin or ginger extracts. Food Chem., 450 (4): 383-388.

24. Fagbenro, O.A., Jauncey, K. (1994b). Chemical and nutritional quality of dried fermented fish silage and their nutritive value for tilapia (Oreochromis niloticus). Animal Feed Sci. Technol.4, 5 (2): 167-176.

25. Fagbenro, O.A., Jauncey, K. (1995). Water stability, nutrient leaching and nutritional properties of moist fermented fish silage diets. Aquacult. Eng., 14 (2): 143-153.

26. Hossain, M.A., Nahar, N., Kamal, M. Islam, M.N., (1992). Nutrient digestibility coefficients of some plant and animal proteins for tilapia (Oreochromis mossambicus). J. Aquacult. Tropics, 7, 257-266. 